\title{
IMPACT OF WORLD TRADE ORGANIZATION ON DEMAND PATTERN AND OPPORTUNITIES TO TEA FARMERS IN NEPAL
}

\author{
Keshav Bhakta Sapkota*
}

\begin{abstract}
Nepal became member of WTO after it adopted open market and economic liberalization policy. Obviously, this kind of membership to WTO could have some kind of implications on Nepalese market. This article is based on the empirical data generated through intensive field work. This article reveals that after Nepal became member of WTO it has direct impact on the demand pattern of Nepalese market. But there is no influence in the creation of new employment opportunities. However, farmers have got different opportunities of getting trainings and access to formal and informal education. More importantly, access to WTO has transformed tea farming from subsistence to commercial and thus increasing the demand of Nepalese tea in international market.
\end{abstract}

Key Words: WTO, demand, employment, Nepal

\section{WORLD TRADE ORGANIZATION (WTO)}

The WTO is an international body which deals with the international trade rules. As a successor to the General Agreement on Trade and Tariff (GATT), the WTO was established in January 1995 with the principle as "to provide the common institutional framework for conducting trade relations among its members in matters related to the agreement" (Article II Marrakesh agreement).

Nepal applied for the membership of GATT, (the predecessor of the WTO), in 1989. However, the efforts for obtaining membership of the GATT could not be materialized due to the long accession process. Nepal has eventually become the $147^{\text {th }}$ member of the global trade regime. The fifth ministerial meeting of the WTO held in September 10-14, 2003 in Cancun, Mexico decided to provide the membership of WTO to Nepal. As Nepal had the experience of initiating the economic liberalization program during mid 1980s and fullfledgelly in early 1990, the WTO accession was not a surprising phenomenon for Nepal.

On 23 April 2004, Nepal has formally been inducted in the WTO as its $147^{\text {th }}$ member. Although there were various groups of opponents who were against the agreement, Nepal's newly acquired membership in the WTO marks the beginning of the expansion of Nepal's international

Dr. Sapkota is Reader in Economics at Birendra Multiple Campus, Tribhuvan University, Bharatpur, Nepal. 
trade integration with global market. It is believed that the WTO brings both opportunities and challenges to poor country like Nepal.

\section{WTO AGREEMENTS AND ITS IMPLICATION ON AGRICULTURE}

Young and Westcott (1998) report that crop insurance subsidies averaged US Dollar 1.4 billion during 1995-98, resulting in an increase of 600000 hectares planted, with wheat and cotton showing the largest percentage gains. Beginning in 2001, U.S. crop insurance subsidy almost double to about U.S. Dollar 3.0 billion owing to the reform by Congress to improve the "safety net" for U.S. farmers (2000: 762-67).

Ministry of Industry, Commerce and Supply (MOICS) and Government of Nepal had their own estimates for SPS and TBT respectively. MOICS, on the one hand, has submitted a report to WTO with a detail action plan for implementing the SPS measures at the time of accession to the WTO. The action plan estimates that it will cost US\$ 12.5 million to introduce an improved Sanitary and Phyto Sanitary (SPS) regime. While the government, on the other, estimates that it needs US\$ 12 million over a five year period to comply with the agreement on Technical Barriers to Trade (TBT). This would cover procuring equipment purchasing consulting services. Similarly, it is estimated that it will cost between US\$ 4 million to US\$ 32 million to fully implement Intellectual Property Right (IPR) law in Nepal. These cost are more than the entire annual budget of many LDCs like Nepal. So, the implementation of WTO rules, agreements and obligations are more problematic for Least Developed Countries (LDCs) (MoICS, 2003).

In this connection, Thapa (2004) in his study, fitted equations for exports and other variables (e.g. time) as follows (t indicates time or years): Tea export $=4.5+7.4 \mathrm{t}$; Tea import $=818-25 \mathrm{t}$ : Unit export price $=$ $1287+136 \mathrm{t}$; and Unit import price $=2161-11$ t. But this study did not establish the relationship between the land holding size and productivity as well as education status of the farmers and their productivity.

Similarly, Awasthi and Adhikari, (2004: 35) in their article, analyzed various provisions of domestic supports measures of Agreement on Agriculture (AoA). Furthermore, their study states about some implications of AoA on Nepalese agriculture sector. It was noted that the AoA disciplines or limits only some forms of subsidies that were production and trade distorting. Thus, there are no supports limits on Green Box measures like agricultural research, extension, agricultural roads etc. Hence, there were no issues here from the WTO standpoint as regards non- exempt support measures that fall under the Amber Box category, express in terms of aggregate measurement of support (AMS), Nepal committed at the time of the WTO Accession to limit these 
subsidies to within the de minimis level, or 10 percent of the Value of the Agriculture Output (VoAP).

They further state that Nepal did not have product -specific AMS as there were no price supports programmers. The study had further added that AoA does not prohibit these programmes for the future provided that the subsidies are limited to the diminimis level. In any case, the amount of subsidies permitted in considerable as regards non product specific AMS (e.g. on fertilizer, irrigations, seeds, credit etc), Nepal can grant these subsidies any time up to the deminimis level. Compare with this limit of 10 percent of the VoAP. In fact, even if the entire government budget on agriculture is assumed to be subsidies, the ratio does not exceed 5 percent. So, the study concludes, as regards the implication of AOA on agriculture sector is that this agreement provides ample room for Nepal to supports its agriculture. The main constraint is resource, not the AoA (ibid).

Chitrakar and Thapa (2004:34-35) in their book, argued that standard related agreement of WTO should be applied by all member countries. But for the LDCs, like Nepal, it is not easy to implement the standard related agreement namely, SPS measures and TBT agreement in various ground. Additionally, they argued and indicated that even the relatively industrialized countries such as China, Argentina and Russia needed US\$ 82.7 million, US\$ 10 million, and US\$ 150 million respectively for implementation of some SPS measures. This accounts for more than the development budget of seven of the twelve LDCs for which no figures had been calculated as implementation costs yet. It implied that the agreements place a much heavier burden of compliance to LDCs most standard were favorable for high technology and capital rich companies and a country like Nepal's Labour incentives manufacturing industry companies cannot take benefit much from the agreements as much. Meanwhile, the cost of the SPS and TBT measures especially in agriculture is very high and the technical assistance to be provided by developed countries is not binding.

\section{CHANGES IN DEMAND PATTERN OF GREEN LEAVES AFTER THE ACCESSION TO WTO}

Market nature and contact with international market have direct bearing on demand pattern. International trade organizations influence the demand pattern. WTO is one of the organizations that influences demand pattern. The condition in demand pattern of green leaves according to the tea farmers are presented in the following table. 
Table-1: Changes in Demand Pattern of Green Leaves after the Accession in WTO

\begin{tabular}{|l|r|r|r|}
\hline \multicolumn{1}{|c|}{ Condition of Change } & Number & Percentage & $\begin{array}{c}\text { Responses } \\
\text { Percent }\end{array}$ \\
\hline Changing noticed & 5 & 3.1 & 13.2 \\
No changing & 25 & 15.4 & 65.8 \\
Little change & 8 & 4.9 & 21.1 \\
\hline & 38 & 23.5 & 100 \\
\hline No answered & 124 & 76.5 & \\
\hline Total: & $\mathbf{1 6 2}$ & $\mathbf{1 0 0}$ & \\
\hline
\end{tabular}

Source: Field Survey, 2008.

Table 1 exhibit that 124 out of 162 respondents did not answer any thing. Just 23.5 percent respondents answered the question. Out of total respondents, 65.8 percent respondents were found that they did not notice any change in demand pattern of green leaf after the accession to WTO. Similarly, 13.2 percent out of 38 respondents noticed change in demand pattern of green leaf after the entry into the WTO. Next 21.1 percent out of 38 respondents felt a slightly change in demand pattern.

Out of 13, 53.8 percent respondents said that organically produced green leaf was in bigger demand than the others. 30.79 percent tea farmers said that farmers who are engaged in the tea cultivation were motivated to produce green leaf under the Code of Conduct $(\mathrm{CoC})$ of Himanalyan Orthodox Tea Planters Association (HOTPA). According to 15.38 percent respondent expressed that Minimum Residue Level (MRL) applied green leaf was more demanded. It indicates that very few farmers were aware about the WTO impact on green leaf demand. Most of them focused on organic green leaf as it was highly demanded. It can be concluded here that, if we want to participate in world market, production method of green leaf should be organic. This is an implication of WTO on green leaf production and more demanding pattern of organically produced green leaf.

\section{EMPLOYMENT CREATION IN TEA SECTOR OF NEPAL}

Nepal has a pre-dominantly rural population similar to other Asian neighbors. About 30,000 family units and more than 40,000 labour forces, with a majority of the workforce being women, were involved in the sector (ITC, 2007). Both the total area and production of tea in Nepal have increased tremendously over the last few years. So, in the tea sector, employment opportunities have also been increasing. 
Similarly, respondents were asked whether the impact of WTO on employment creation was positive or negative. Their responses are presented in Table-2.

Table-2: Impact of WTO on Employment Creation

\begin{tabular}{|l|r|r|r|}
\hline \multicolumn{1}{|c|}{$\begin{array}{c}\text { Impact } \\
\text { Experiences }\end{array}$} & \multicolumn{1}{|c|}{ Number } & Percentage & $\begin{array}{c}\text { Responses } \\
\text { Percent }\end{array}$ \\
\hline Positive Impact & 48 & 29.63 & 39.67 \\
Negative Impact & 3 & 1.85 & 2.48 \\
No Change at all & 70 & 43.21 & 57.85 \\
\hline Total & 121 & & 100.00 \\
\hline No Response & 41 & 25.31 & \\
\hline Total: & $\mathbf{1 6 2}$ & & \\
\hline
\end{tabular}

Source: Field Survey, 2008.

Table- 2 shows that 39.67 percent out of 121 respondents said that after Nepal's accession in WTO, its impact on tea sector employment creation has been positive. Likewise 2.48 percent respondents said its impact on tea sector was negative and 57.85 percent respondents said there was no change at all in employment creation after the accession in WTO of Nepal.

Those respondents who answered as positive impact of WTO on tea sector mainly due to the extension of their farm size and at the same time some tea planters were adding the technical manpower for good agricultural practices which created some new jobs on the tea sector. Three respondents out of one hundred sixty two were found to be argued that impact of WTO on employment creation is negative. Mainly, due to the decline pattern of green leaves price tea planter/farmers were not devoted on tea garden management in a good manner. Result of this situation was negative on tea sector employment. A total of 70 respondents out of 162 found their experiences of WTO impact on employment as having no change at all. According to them, decreasing price and increasing cost of production was the main cause of constant level of employment. As a result, farmers were not encouraged to extension of their farm size, although there is potentiality of extension. However they had additional land to plantation of tea. Therefore, employment on tea sector was not changed. Thus, it can concluded that job creation on tea sector is possible if green leaf price trend is up warded 
or reasonable price gets according to their cost of production will be paid to the farmers.

\section{Figure-1}

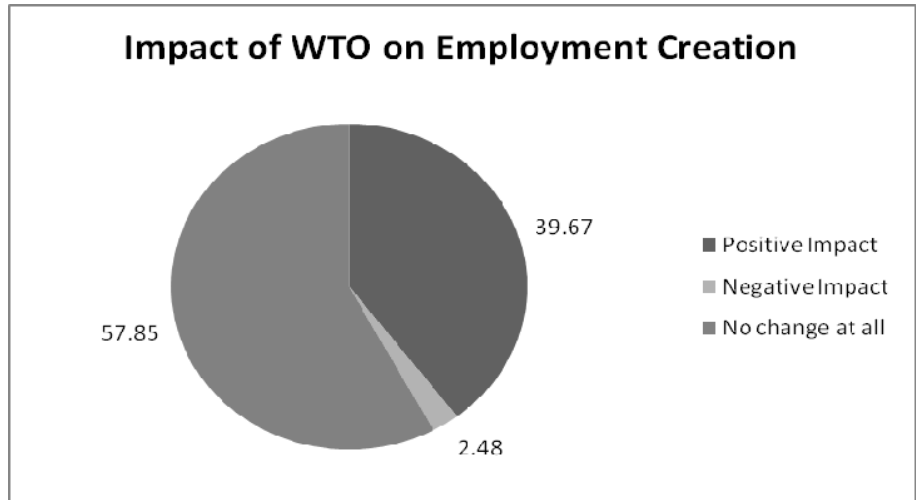

Source: Field Survey, 2008.

Figure-1 shows the impact of WTO on employment creation. Most of the participants of focus group discussion argued that after the WTO membership too there was no new opportunity for employment.

\section{KNOWLEDGE ABOUT THE WTO AGREEMENT}

Agreement on Agriculture (AoA), Sanitary Phyto Sanitary (SPS) measures, Technical Barriers on Trade (TBT) and Trade Related Intellectual Property Rights (TRIPs) are more concerned agreements of WTO for Nepalese agriculture. In this regard, to find out whether these agreements were affecting or not in tea farming of Nepal and at the same time, what was the understanding level of the tea planters/farmers on the above mentioned agreement, was the concerning aspect of this study. The following table presents the responses of the respondents on WTO agreement:

Table-3: Knowledge about the WTO Agreement

\begin{tabular}{|l|c|c|c|l|c|c|}
\hline & & & \multicolumn{4}{|c|}{ Known Respondents } \\
\cline { 4 - 7 } $\begin{array}{c}\text { Understanding } \\
\text { Position }\end{array}$ & Number & Percent & S.N. & $\begin{array}{l}\text { Application } \\
\text { of WTO } \\
\text { Agreement }\end{array}$ & No & Percent \\
\hline Known & 19 & 11.70 & 1. & $\begin{array}{l}\text { Tea plantation } \\
\text { with MRL } \\
\text { application }\end{array}$ & 15 & 78.9 \\
\hline Unknown & 143 & 88.30 & 2. & $\begin{array}{l}\text { SPS } \\
\text { measures/food } \\
\text { safety } \\
\text { measures }\end{array}$ & 4 & 21.1 \\
\hline Total: & $\mathbf{1 6 2}$ & $\mathbf{1 0 0 . 0 0}$ & & & & \\
\hline
\end{tabular}

Source: Field Survey, 2008. 
Table-3 depicts that 19 out of 162 respondents were found to have said that they were familiar about the WTO agreement like, AoA, SPS and others. Those who belonged to higher education status were simply literate about the WTO and its agreements. Majority of the farmers were not able to understand the WTO and its agreements. Out of 162 respondents 88.3 percent said that they were uninformed about the WTO and its agreements.

Among the selected respondents, 78.9 percent were found to have been following the WTO and its agreements as MRL implementation in tea cultivation. It indicates that use of pesticide/insecticide should be at minimum level as prescribed. The tea farmers mainly belonged to Ilam district, were found to have decreasing tendency in application of chemical fertilizer and pesticide/insecticide. These farmers were inclined towards the organic tea farming which had more demand in world market especially in the developed world. 21.1 percent respondents said that for the implementation of sanitary and Phyto-Sanitary (SPS) measures of WTO, they were conscious about the food product which should be safe for human consumption.

Figure- 2

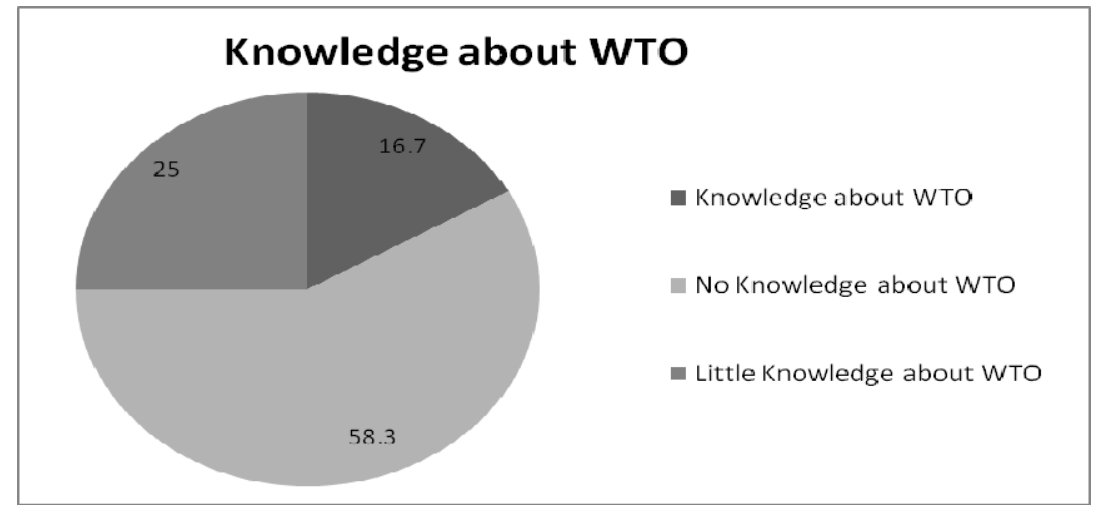

Source: Field Survey, 2008.

Figure-2 shows the knowledge about the WTO. According to the figure, $16.7 \%$ respondents knew what WTO was and what it did and $25 \%$ repondents were unfamiliar with this while $58.3 \%$ respontets had little knowledge of WTO.

\section{PRESENT CONDITION AND SUPPORT NEEDED}

TRANSPORTATION CONDITION AND COST

Transportation is the most important infrastructure to develop the tea sector. But most of the green leaf farmers are located in areas, where infrastructure is poor. Although, they are able to produce the leaves in quantities, method of transportation, such as an animal back, bicycles 
which are unsatisfactory because of they cause damage to the leaves in transit. Access to the farmer's premises quickly with suitable vehicles should be made available. After the plucking of green leaf, generally, with base of quality concern it should be brought at the factory premises within 3 hours. So, the transportation facility and means of transportation is vital concern in quality aspect of tea. Data on road condition, distance, means and cost of transportation is given in following Table-4.

Table-4: Road Condition, Distance, Means and Cost of Production

\begin{tabular}{|c|c|c|c|c|c|c|c|c|c|c|c|c|c|c|c|c|c|c|c|c|c|c|c|c|c|}
\hline \multirow{2}{*}{\multicolumn{6}{|c|}{$\begin{array}{c}\text { Distance } \\
\text { Km from Green Leaf } \\
\text { Production Area to the } \\
\text { Market }\end{array}$}} & \multicolumn{8}{|c|}{ Means of Transportation } & \multicolumn{6}{|c|}{ Road Condition } & \multirow{2}{*}{\multicolumn{6}{|c|}{$\begin{array}{c}\text { Cost Transportation } \\
\text { Kg/Rs. }\end{array}$}} \\
\hline & & & & & & \multirow{2}{*}{\multicolumn{2}{|c|}{$\begin{array}{l}\text { Riksha } \\
\text { Van }\end{array}$}} & \multirow{2}{*}{\multicolumn{2}{|c|}{$\begin{array}{l}\text { Hor } \\
\text { se }\end{array}$}} & \multirow{2}{*}{\multicolumn{2}{|c|}{ Man }} & & & \multirow{2}{*}{\multicolumn{2}{|c|}{$\begin{array}{l}\text { Black } \\
\text { Toped }\end{array}$}} & \multirow{2}{*}{\multicolumn{2}{|c|}{$\begin{array}{c}\text { Grave } \\
\text { led }\end{array}$}} & \multirow{2}{*}{\multicolumn{2}{|c|}{$\begin{array}{l}\text { Fare- } \\
\text { Weathe }\end{array}$}} & & & & & & \\
\hline \multicolumn{2}{|c|}{ 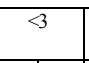 } & \multicolumn{2}{|c|}{$>3<6$} & \multicolumn{2}{|c|}{$>6$} & & & & & & & & & & & & & & & $\begin{array}{l}<1 \\
\text { Rs. }\end{array}$ & & $1<2$ & & $>2 \mathrm{Rs}$ & \\
\hline$\stackrel{2}{2}$ & $\therefore$ & z & $\therefore$ & ฉ & $\therefore$ & $\stackrel{2}{2}$ & $\therefore$ & 2 & $\therefore$ & 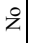 & $\therefore$ & $\stackrel{2}{z}$ & $\therefore$ & $\stackrel{2}{z}$ & $\therefore$ & ฉ & $\circ^{\circ}$ & $\approx$ & $\therefore$ & 2 & $\therefore$ & $\stackrel{8}{z}$ & $\therefore$ & 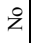 & $\therefore^{\circ}$ \\
\hline$\therefore$ & $\stackrel{?}{m}$ & 5 & $\hat{q}$ & ले & 견 & 2 & $\partial$ & के & สิ) & స & ป் & t & $\overrightarrow{\mathrm{g}}$ & in & $\begin{array}{c}\infty \\
\dot{\infty} \\
\stackrel{p}{n}\end{array}$ & मे & $\vec{a}$ & $\because$ & $\vec{\phi}$ & 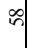 & $\approx$ & \pm & $\stackrel{\infty}{\infty}$ & $\sim$ & $\vec{i}$ \\
\hline
\end{tabular}

Source: Field Survey, 2008.

Road condition has been classified into three categories. They are black topped, graveled and fair weather. Black topped, graveled and fair weather road are 38.8, 23.1 and 38.1 percent respectively. It indicates that nearly about two-third part of the road is not well. Low grade road increases the cost of transportation and length of delivery of green leaf into the factory premises and quality green leaf can deteriorate.

Cost of transportation of green leaves in the study area is classified into the three groups. One is the category of less than Re $1 / \mathrm{kg}$. Within this group 78.4 percent respondents were found. Second classification was 12 Rs $/ \mathrm{kg}$ and third was $2 \mathrm{Rs} / \mathrm{kg}$. 18.9 and 2.9 percent respondents were found as second and third classification respectively.

\section{CREDIT FACILITY/TAKEN FROM}

Proper investment is needed to the development of the tea sector. For it financial position of tea planter should be managed in whatever the way, may be possible either from bank/financial institutions or by himself. Tea planting in Nepal is small and mainly small land holder's are engaged in this sector. So, there is no need of large amount credit. However, small amount is needed to start tea cultivation and maintain the gardens. Tea cultivation has been financed largely from the resources of the households themselves. Everyone hasn't taken loan, and even those who have borrowed loan from the bank, have not been always and exclusively using the fund for meeting expenditure related to tea plantation. Tea farmers would like to take loan from the bank only because of the low interest rate 
than that of local money lenders. But taking loan from Bank has not been attractive because of the difficulties in the process and prompt sanction. Several households felt that there was need of soft loan for expansion of tea cultivation. They also express that the loan taking process should be simple. However, field data exhibit that out of 162 respondents 64.8 percent respondents had taken loan from the different sources, which is shown in Table-5.

Table-5: Sources of Credit Acquisition

\begin{tabular}{|l|r|r|r|}
\hline \multicolumn{1}{|c|}{ Sources } & \multicolumn{1}{c|}{ Number } & \multicolumn{1}{c|}{ Percentage } & $\begin{array}{c}\text { Responded } \\
\text { Percentage }\end{array}$ \\
\hline Commercial Bank & 6 & 3.7 & 5.0 \\
\hline ADB/N & 72 & 44.4 & 59.5 \\
\hline Financial/Institution & 4 & 2.5 & 3.3 \\
\hline Co-operatives & 23 & 14.2 & 19.2 \\
\hline $\begin{array}{l}\text { Local Money } \\
\text { Lender }\end{array}$ & 16 & 9.9 & 13.2 \\
\hline No Response & 41 & 25.3 & \\
\hline Total: & $\mathbf{1 6 2}$ & $\mathbf{1 0 0 . 0 0}$ & $\mathbf{1 0 0}$ \\
\hline
\end{tabular}

Source: Field Survey, 2008.

It is obvious that amongst the respondents 59.5 percent farmers took loan from the Agricultural Development Bank of Nepal $(A D B / N)$ followed by co-operatives and local money lender. Very few farmers took credit from commercial banks and financial institutions. Data indicate that $\mathrm{ADB} / \mathrm{N}$ is a major source of credit for the tea planter. Co-operative organizations and local money lender were $2^{\text {nd }}$ and $3^{\text {rd }}$ sources of credit for the tea planter in study area. But 41 respondents out of 162 did not response about any sources of credit. It means that they were managing financial aspect by themselves.

\section{AUCTION MARKET}

Nepal has a dual manufacturing base. It produces Cut, tear and curl (CTC) and Orthodox type of tea. Nepal's tea production is minimal in comparison to global market. The volume of production is 0.48 percent and currently exported volume is around 0.56 percent, out of total global output (ITC, 2010). So, establishment of global auction market in Nepal has low potentiality. 
Auction market is necessary factor for giving encouragement to the production/distribution of tea. Roughly 70 percent of global tea production is traded at auction (ITC, 2007). The rest is effectuated through private sales. Nowadays, the main centers are in India (Kolkata and Kochi), Sri Lanka (Colombo) and Kenya (Mombassa). The latter is also the auction centre for many other African tea producing countries. Some other important tea-producing countries, such as China, Argentina and Turkey, do not have an auction system. However for Nepal, according to field report data 142 out of 162 respondents said that auction market was necessary factor for tea trade. Transparency of price, knowledge about the international tea market and price according to quality and grade were the main benefits of auction market. 58.6 percent respondents answered as price fixation and transparencies in price fixing were the benefit of auction. So, it is needed in Nepal as well.

Although all of 12 respondents, from tea processing factories, both CTC and Orthodox type tea producers, felt need of auction market. But one respondent from CTC type said that Nepal's production of tea was very limited in quantity so its establishment and good operation was very difficult. According to him it can be run with full cooperation and support from the government.

Almost all the respondents from exporters said that auction market was necessary to enhance the tea market. According to the respondents who were surveyed regarding the issue of auction market said that it was beneficial for the price fixation according to quality/grade, price transparency, communication with local buyers and price competition. This fact was further proved by the participants of focus group discussion as well.

\section{INFORMATION ACCESS ON INTERNATIONAL MARKET}

Tea is a processed agricultural product, which is traded in the world market. For this reason, it is better to highlight about the overall situation of tea globally, like production and consumption situation, tea producing countries, prices of leave and readymade tea, auction market etc. not only for tea processing factory and exporters but also for tea farmers. International tea market information accesses through different media are shown in following table 6. Field report data show that 72.8 percent tea planters were found to have no access to international market. 25.3 percent out of 162 respondents were found to have access of information about international tea market through Radio, TV, Newspaper 
but just 1.9 percent respondents have access information through personal link by Telephone and Internet.

Table-6: International Tea Market Information Access through Different Media

\begin{tabular}{|l|c|c|}
\hline \multicolumn{1}{|c|}{ Media Access } & Number & Percent \\
\hline Radio, TV, Newspaper & 41 & 25.3 \\
\hline Telephone/Internet & 3 & 1.9 \\
\hline No media access & 118 & 72.8 \\
\hline Total: & $\mathbf{1 6 2}$ & $\mathbf{1 0 0 . 0 0}$ \\
\hline
\end{tabular}

Source: Field Survey, 2008.

\section{CHANGING OF DEMAND PATTERN OF NEPALESE TEA IN INTERNATIONAL MARKET}

Demand pattern of Nepalese tea in international market has been changed for the last 10 years. This situation was experienced by the respondents. All of the five respondents (exporters) felt that there was change in demand pattern at the international market. Among the five exporters one said that there was no organic certification, as a result, European market has been down. Similarly, three out of five said that there was change in demand pattern due to the beginning of fair trade and participation in such occasion. As a result, publicity, quality improvement, specialty produce type of tea was highly demanded in international market. Mainly, respondents focused on organic and quality certification, fair trade and specialty production of tea to grab the global demand of tea.

\section{EFFECTS OF CHEAP IMPORTED PRODUCT ON EXPORT}

According to the field data, all the five respondents said there was no cheap import of tea, but there was existence of quality import. So, due to this reason there was not an important question about cheap imports of tea and its effect on tea.

They were not damaging the profession by cheap import according to all five exporters. But among the respondents, one said that import of tea did not damage the profession but there is effect on export of Nepalese tea, as making less price, less demand, has reduced income and reducing the capacity.

\section{IMPACT OF WTO ON EXPORT/EXPORTERS OF TEA}

In this study exporters were asked what they experienced on tea export after the accession of Nepal into the WTO? Their responses presented in table 7. 
Table-7: Experiences of Exporters, After Entering in to the WTO

\begin{tabular}{|l|c|c|c|c|c|}
\hline \multirow{2}{*}{\multicolumn{1}{c|}{ Experiences }} & \multicolumn{5}{c|}{ Ranking } \\
\cline { 2 - 6 } & $\mathbf{5}$ & $\mathbf{4}$ & $\mathbf{3}$ & $\mathbf{2}$ & $\mathbf{1}$ \\
\hline Harmful & - & - & - & 3 & 2 \\
\hline Beneficial & 2 & 3 & - & - & - \\
\hline More competitive & 2 & 1 & 2 & - & - \\
\hline Need to improve quality & 5 & - & - & - & - \\
\hline Market damaging & - & - & - & 1 & 4 \\
\hline
\end{tabular}

Source: Field Survey, 2008.

According to Table, tea exporters had found it beneficial to export tea after entering of Nepal into the WTO. Out of 5 respondents 2 and 3 gave highest scale 5 and 4 respectively for the beneficial experiences. Due to the market access opportunity of WTO agreement exporters could grab the opportunity as per the response of respondents.

All the respondents said there was need to improve quality of tea to take the global market. They gave the highest rank to improve quality. According to their preference, without quality or competitive product the space in global market would not be occupied. Tea exporters had experienced that global market would be more competitive after the entry into the WTO. Out of 5 exporters 2 rated highest rank for market would be more competitive. One and 2 respondents respectively rated $2^{\text {nd }}$ and $3^{\text {rd }}$ option for market is being more competitive.

After the entry into WTO, exporting condition of tea is not harmful and market damaging condition may not occur as per the response of the respondents because they did not focus on it. Most of the respondents rated lowest scale for this condition which would not be harmful and market damaging after entering into the WTO. Consumers of developed countries are more conscious about the quality/organic product. According to them, if Nepal's product was qualitative and organic, export potentiality of Nepalese tea would be high in international market.

EXPORT AND POLICY RELATED INFORMATION ON TEA EXPORTERS

\section{FACTORS FOR BETTER EXPORT}

Different factors are responsible for the export of tea. If a country can export large quantity of product with high quality, it is called better 
export of the production. Field data show that for better exporting of tea there must be government support, quality production, chemical free certification, good manufacturing practices (GMP) and transportation and transit facilities. Factors responsible for better export are shown in the following table.

Table-8: Factors for Better Export

\begin{tabular}{|l|c|}
\hline \multicolumn{1}{|c|}{ Factors } & Number \\
\hline Quality product & 3 \\
\hline Government support & 4 \\
\hline Chemical free & 2 \\
\hline Certification & 3 \\
\hline GMP & 3 \\
\hline Transportation/Transit & 2 \\
\hline
\end{tabular}

Source: Field Survey, 2008.

The above table reveals that 4 out of 5 respondents said that government support programme (scheme to the exporters) was the most important factor for better export of tea. From the side of government, support scheme like, export credit with subsidized rate, market searching support, transportation and transit support, packaging material support etc may be included in this support. In availability of this support, export can be promoted. Likewise, quality with chemical free product is other factor for better export. In the global tea market, organic and $1^{\text {st }}$ grade quality tea, are highly demanded. In this study, 3 respondents focused on quality and chemical free product of tea for the better exporting. Quality and organic certification is essential for better export of tea globally as 3 respondents reported. In good manufacturing practices (GMP) good handling, processing, storage and packaging etc. works are included. For the maintenance of quality GMP should be done. As a result, export of tea will be better for which 3 respondents had focused on. Transportation/transit facility is also necessary for better export of tea. Without this facility exporters can't increase their export in quantity.

\section{RELATIVE QUALITY OF NEPALESE TEA IN INTERNATIONAL MARKET}

Relatively medium quality of Nepalese tea in international market is neither inferior nor superior. Its relative quality in international market is in between excellent and poor. As per the relative quality 2 out of 5 
exporters said relative quality of Nepalese tea was excellent than the others and 3 said it was good. According to them, relatively Nepalese tea was not poor in global market. So, none of them said quality of Nepalese tea was poor in comparison to others.

The information obtained through focused group discussion reveals that quality of green leaves in Nepal was relatively better, due to the youngness of the tea bushes good tips, clone variety and climatic condition . Quality of Nepalese tea is neither poor nor excellent. It is good in international market.

\section{STRATEGIC ALLIANCE WITH FOREIGN FiRMS}

Export promotion strategy with foreign firms is necessary to enhance the export of a product. There are many firms in the global tea market which can affect the tea market situation, like demand pattern, prices, production and consuming habits. Alliance of tea exporters with the foreign firms lacks in Nepal. According to the field data only one respondent had a trade agreement with Japanese and Germany party. But 4 out of 5 exporters had not any strategic alliance with foreign firms. This situation indicates that Nepalese exporters' capability to build the relation/alliance is very weak. In this competitive age, to grab the global market there must be alliance with foreign firms.

\section{INFORMATION ACCESS OF EXPORTERS}

Tea is traded in world market. For this reason it is necessary to understand the world market situation of tea; like consumption pattern/habit according to tea quality, producing countries, price situation, auction market, world production situation etc for the tea exporters. Field data show that all the 5 respondents have e-mail and internet facility for the access on information. But among them 3 respondents had remarked about the information access that their access on information is not strong, News letter, magazine, tea time and tea related literature were another sources of information for them. It is found that 4 out of 5 have access on information through newspaper, magazine and related literature of tea. Three respondents have access to personal contact through telephone. This is the age of communication and different types of Medias are being developed worldwide. According to field data, they have access in information, but not in strong position, all of them felt it.

\section{CONCLUSION}

Nepal applied for the membership of GATT, (the predecessor of the WTO), in 1989. However, the efforts for obtaining membership of the GATT could not materialize due to the long accession process. Nepal has 
eventually become the $147^{\text {th }}$ member of the global trade regime. As explained by many scholars including Awasthi and Adhikari there were some implications WTO in terms of AoA on Nepalese agriculture sector. It was noted that the AoA disciplines or limits only some forms of subsidies that are production and trade distorting. Market nature and contact with international market have direct bearing on demand pattern as well. International trade organizations influence the demand pattern. WTO is one of the organizations that is influencing demand pattern in international market. The relation of any country to international market obviously influences local market. However, in the context of Nepal, very few farmers have noticed in this kind of demand pattern. As a result, farmers are not encouraged to extension of their farm size, although there is potentiality of extension. However they have additional land to plantation of tea. Therefore, there is no change in employment status. Neither it has increased nor decreased. We can conclude that job creation on tea sector is possible if green leaf price trend is up warded or reasonable price gets according to their cost of production will be paid to the farmers. However, farmers in tea sectors are getting opportunities of borrowing loans, investing it in production tea, training facilities, exposure to international market, access to export and so on.

\section{WORKS CITED}

Awasthi, D.B. \& Adhikari, S.K. (2004). "Agreement on agriculture: Domestic support measures". In: Implication of the WTO membership on Nepalese agriculture. FAO and UNDP in collaboration with MoICS, HMGN, Kathmandu, Nepal.

Chitrakar, R. \& Thapa, D. (2004). International trade and standard: A South Asian perspective. V+30, Kathmandu: SAWTEE.

ITC \& TEPC (2007). Export potential assessment in Nepal. Kathmandu: Implemented by the International Trade Centre (ITC) Market Analysis Section, in Collaboration with the Trade and Export Promotion Centre (TEPC) of Nepal.

ITC (2010). International tea committee report. Annual Bulletin of Statistics 2010.

MoICS (2004). Nepal trade and competitiveness study. Ministry of Industry, Commerce and Supplies: Kathmandu, Nepal.

--- (2004/05). Nepal overseas trade statistics. Kathmandu: GON, Ministry of Industry, Commerce and Supplies, Nepal. 
Thapa, Y.B. (2004). "Commodity case study-tea". In: Implications of the WTO membership on the Nepalese agriculture. Kathmandu: FAO/UNDP in Collaboration with MOAC, HMGN,

WTO (2000). "Export subsidies". Background paper by the secretariat, Document G/AG/NG/S/5, 11 May 2000.

--- (2003). "Report of the working party on the accession of the Kingdom of Nepal to the WTO". Document WT/ACC/NPL/16, 28 August 2003.

--- (2004). World trade report. Geneva.

Young, E.J. Westcott (2000). "How Decoupled is U.S. agricultural support for major crops?" American journal of agricultural economics. 82 (3): 762-67. 